\title{
Refuge
}

Canada's Journal on Refugees

revue canadienne sur les réfugiés

\section{Carceral Humanitarianism: Logics of Refugee Detention by Kelly Oliver}

\section{Christian Williams}

Volume 35, Number 1, 2019

Racialized Refuge

URI: https://id.erudit.org/iderudit/1060679ar

DOI: https://doi.org/10.7202/1060679ar

See table of contents

Publisher(s)

Centre for Refugee Studies, York University

ISSN

0229-5113 (print)

1920-7336 (digital)

Explore this journal

Cite this review

Williams, C. (2019). Review of [Carceral Humanitarianism: Logics of Refugee Detention by Kelly Oliver]. Refuge, 35(1), 86-87.

https://doi.org/10.7202/1060679ar

This document is protected by copyright law. Use of the services of Erudit (including reproduction) is subject to its terms and conditions, which can be viewed online.

https://apropos.erudit.org/en/users/policy-on-use/ 


\section{Carceral Humanitarianism: Logics of Refugee Detention \\ $\sim$}

Kelly Oliver

Minneapolis: University of Minnesota Press, 2017, 92 pp.

$\mathrm{I}$ $\mathrm{n}$ this book Kelly Oliver makes a poignant case for the value of a critical, deconstructive approach to examining humanitarianism generally and refugee work in particular. As Oliver asserts, humanitarian practices today work in tandem with state violence to control populations in the context of the war on terror. In turn, "the military approach that treats refugees like prisoners of war ... is fused with the humanitarian approach that treats refugees as charity cases to be rescued and saved" (7). This and related points are developed in short, thematically organized chapters, which are not only theoretically rich, but also accessible to the general reader interested in thinking more deeply about such pressing social issues.

In developing her argument, Oliver draws (sometimes explicitly, more often implicitly) from well-worn stances in the critical scholarship on humanitarianism. As this literature maintains, refugees transgress the global political order, which organizes people and territory into discrete nationstates, even as it consolidates this order through labelling some people "refugees" and managing those so labelled through humanitarian government. Discourse that presents refugees as apolitical victims and spaces that separate refugees from legitimate political action are crucial to this process of consolidation because they render complex politics surrounding human displacement as if they were beyond the pale of discussion.

In addition to reinforcing these general points, Oliver develops several more specific arguments, drawing especially from the work of Jacques Derrida, her main interlocutor in this text. I find two of these arguments particularly compelling. The first involves the paradoxical relationship between contemporary humanitarian work and genocidal violence. As Oliver maintains, political leaders, military commanders, and humanitarian workers are all increasingly involved in cost-benefit analyses aimed at avoiding "the worst" consequences of their efforts to control human populations. Since the Second World War, the worst has often been associated with Nazi Germany's “final solution." Nevertheless, as Oliver argues, the very act of reducing people to numbers whose lives and deaths may be calculated creates the very conditions in which "the worst" may again occur. If there is one group that is particularly vulnerable to this genocidal logic today, it is refugees-an entire category of people excluded from the rights of citizens and often living in such precarious conditions that they hang on the edge of life and death. In developing this point, Oliver is, of course, working with Giorgio Agamben's seminal argument about the bio-politics of camps, which, regardless of whether understood in terms of concentration camps or refugee camps, reduces inhabitants to "bare life." At the same time, Oliver draws our attention to a more specific bio-political context, in which calculations concerning refugees entangled in the war on terror threaten us with the worst.

Second, Oliver, again following Derrida, presents an alternative approach to humanitarianism that works on principles that are fundamentally different from the present-day humanitarian regime. As she maintains, the idea of humanitarianism as it has evolved over the past several hundred years rests on notions of sovereignty wherein the sovereign power gives to those encroaching on its domain from a position of authority. Hospitality, or what Oliver often refers to as "radical hospitality," demands more of us than this, however. It demands that we move from a rights-based understanding of political obligations towards a politics grounded in "our interdependence on this shared planet" (83). It may even require those of us who produce information about refugees to submit to "a certain 'madness" by giving up the will to develop responses to people crossing international borders primarily on the basis of understanding or knowledge (79). As Oliver powerfully concludes, "Without holding on to the concept of [radical] hospitality, our everyday practices of hospitality are hollow, illusions of hospitality and self-deception at best, or alibis for continued violence at worst" (82).

Despite these provocative and productive views, Oliver's text suffers from shortcomings common to much scholarly work that presents contemporary humanitarian government from an abstract perspective. For example, Oliver repeatedly draws from decontextualized data to make claims about what it is like to be a refugee today. Claims include references to how female refugees are affected by gender violence (23), the prevalence of post-traumatic stress disorder (PTSD) among refugees (32), and the "involuntary" quality of refugee migration (33). My point here is not to diminish the extent to which many refugees' experiences are reflected in these claims, but rather to contest the idea that refugees can and should be seen as an ideal type with a 
generic experience, when the causes and aftermaths of displacement vary immensely. Similarly, Oliver's presentation of humanitarianism's history presents a straight line between Western political thought and present-day "carceral humanitarianism" without acknowledging any alternative histories that cut across regional traditions or divides. And yet, such histories do exist. For example, contrary to Oliver's brief discussion of humanitarianism and Afro-Asian decolonization (51-2), a great deal of humanitarian work with refugees in Southern Africa during the late twentieth century took sides in the region's political struggles, forging new humanitarian ideas across Cold War and global North-South divisions.

One might argue that these shortcomings in Oliver's work reflect the limitations of the genre in which she writes. Indeed, how much attention can one offer to the complexity of refugee experience and histories in such a short, accessible text, published in a series committed to "thought-in-process" rather than "finished books" (i)? Regardless, I believe that even a text such as this one would do well to discuss the relationship between universalizing refugee representations and particular refugee histories. In so doing, the author might not only deepen her analysis of the origins of "carceral humanitarianism" but also provide further insight into how we may move beyond this condition through attention to the contexts wherein refugee hosts are called to be hospitable.

Christian A. Williams is a senior lecturer in the Department of Anthropology in the University of the Free State, South Africa. The author may be contacted at cawooo4@yahoo.com.

\title{
American Routes
}

\author{
n \\ Angel Adams Parham \\ New York: Oxford University Press, 2017, 296 pp.
}

A merican Routes, by Angel Adams Parham, offers an insightful look into the historical development and contemporary vestige of overlying, competing registers of race emerging from and interconnected with migratory flows. Considering both black and white St. Domingue/ Haitian refugees and their Creole descendants in Louisiana, Parham comparatively assesses immigrant integration within a multilayered racial system, as a process perforated by transhistorical complexity, variability, and resistance. The book centralizes race as a fundamental dimension of immigrant integration, and, in this way, Parham's work cogently brings into critical dialogue the field of migration studies and the sociology of race and racism.

Anchoring her work in time and space, Parham crafts what she describes as a racial palimpsest approach to explicate the intricacies of long-term racial integration for Creoles in Louisiana. It is here that Parham's most significant contribution is advanced: the analysis of black and white Creoles illustrates how disparate racial systems and logics co-exist through space and time and come to inform immigrant struggles over competing racial frameworks, social integration, and self-identification practices. The racial palimpsest approach offers an ontological posture that assumes racial inequality and racialization as part of the reception and daily struggles of immigrants. The analysis departs from the Eurocentricity of assimilationist frames devoid of racial considerations, often taking the European immigrant as the primary and relative figure, and instead insists upon the significance of race and racism in shaping the experiences of non-European, non-white immigrants.

A number of methods were employed to collect the data that map racialized integration in Louisiana, including participant observations, in-depth interviews, oral histories, and archival work. The book's rich empirical data reveal how both black and white Creole subjects engage with the logics of two coinciding racial systems, either as a means to maintain a system that helps bolster their well-being or to resist the adverse impacts of another. The core comparative chapters of the book (chapters 3-6) are structured to demonstrate the historical fashioning and enduring fragments of the racial palimpsest in Louisiana, along with the diverse ways in which white and black Creoles negotiate their identities and reinscribe these systems from the nineteenth century into the present.

Following the arrival of St. Domingue/Haitian refugees to Louisiana in the early nineteenth century, the foundational triracial Latin/Caribbean system based on colour, class, and status (white / free black / enslaved black) was reinforced as both white and black refugees sanctioned its social and political dimensions. During this period, white Creoles sought to preserve this triracial system, but eventually the difficulty of retaining their ethnocultural and racial identification as white Creoles was rendered incompatible with the AngloAmerican binary standard of whiteness as biological purity. Consequently, integrating into the Anglo-American notion 